\title{
Effects of Tax Evasion and Tax Policy on Economic and Social Environment: The Case of Bosnia and Herzegovina
}

\author{
Saudin Terzić ${ }^{1}$ \& Miro Džakula ${ }^{2}$ \\ ${ }^{1}$ M.Sc., PhD student (doctorant) on Faculty of Economics at the University of Banja Luka, Bosnia and Herzegovina \\ ${ }^{2}$ Ph.D., Professor on Faculty of Economics at the University of Mostar, Bosnia and Herzegovina, Director Indirect \\ Taxation Authority in Bosnia and Herzegovina
}

Correspondence: Saudin Terzić, M.Sc., PhD student (doctorant) on Faculty of Economics at the University of Banja Luka, Bosnia and Herzegovina.

\author{
Received: December 5, 2018 Accepted: January 9, $2019 \quad$ Available online: January 24, 2019 \\ doi:10.11114/aef.v6i2.3836 \\ URL: https://doi.org/10.11114/aef.v6i2.3836
}

\begin{abstract}
Bosnia and Herzegovina $(\mathrm{BiH})$ is still at an early stage in development of functional economic and social environment. "How do tax evasion and tax policy effect on economic and social environment?" This is one of the key issues that requires full attention of fiscal policy and is also the hypothesis of this study. Is tax evasion in direct correlation with the economic welfare of a society, social environment and economic activity? The effort to shed light on these questions can help in the implementation of measures and activities on the prevention and suppression of tax evasion.

In the focus of interests of this study are two groups of respondents, the taxpayers on one side who make contacts with professional groups on the other side employed in tax administrations (inspectors). For the purpose of analysing the collected data, the statistical package of SPSS was used. The contribution of this research and the main research result indicate that tax evasion has multiplicative effects, it destroys the reputation of institutions primarily and in particular the reputation of the tax administration, it poses a threat to the tax system and rule of law, causing taxpayer's distrust of the tax system itself. Thus, by reducing tax evasion the situation in public finances improves substantially. The study shows the theoretical analysis of the phenomenon of tax evasion in $\mathrm{BiH}$ (which is not a goal in itself), including analysis of current tax procedures and tax policy of $\mathrm{BiH}$ and their influence on economic and social environment.
\end{abstract}

Keywords: taxation, tax policy, tax evasion

JEL classification: H20, H21, H26.

\section{Introduction}

The taxes being the basic source of funds for the state budget determine the amount of social benefits. How to protect the tax system against potential frauds and abuse - this is one of the main issues of the fiscal authorities. The main objectives of every tax administration are: which mechanisms to use in order to fight against tax evasion and reduce the grey market, as well as tax revenue collection. While the shadow economy and tax evasion are not congruent, in most cases activities in the shadow economy imply the evasion of direct or indirect taxes, such that factors determining tax evasion will most certainly also affect the shadow economy (Schneider, Buehn, 2016, p.3).

Modern business is characterized by numerous, big and turbulent changes, increasing liberalization and globalization, increased taxpayer mobility, growth and accelerated development of regulatory standards, and in this domain the issue of tax evasion gains a special dimension and becomes very important not only for tax authorities that are implementing the tax regulations but also for taxpayers themselves. It is known that tax evasion involves our everyday life (Russo, 2010, p.3). Is tax evasion a hot topic in economics and social sciences (Kirchler, 2009, p.1)? Based on the search term "tax evasion" at the specialist academic search engine google scholar 143,000 articles were found (searched, 23.11.2016). The functioning of the tax system and taxation in one economy is of crucial importance to overall financial stability, and tax evasion is one of the major risks if not addressed adequately, and, depending on the amount of taxes evaded, can trigger severe financial instability in a country. For that purpose, the issue of tax evasion is always raised and nowadays it constitutes one of the most complex but also very important tax issues in the functioning of national institutions, since the tax system in a modern state is the central pillar of the overall financial system and without it 
functioning properly, no efficient economic policy can be implemented.

Tax Evasion is widely studied by Allingham, Sandmo (1972), Pyle (1989), McGee, Tyler (2006), Kirchler (2009), Russo (2010), Turner (2010), Alm (2012), Pickhardt, Prinz (2013) and many others.

Tax evasion is a world phenomenon, and surely is not a new phenomenon. It's almost as old as the world is and there are so many ways of tax evasion. The problem (tax evasion) is particularly acute in transition countries and developing countries, for those who do not have well-developed revenue collection infrastructure (McGee, Tyler. 2006:1). Tax evasion limits a government's ability to raise revenues in order to meet budget requirements (Turner, 2010). Numerous economists have a different view on tax evasion. Some of them tend to see tax evasion as a technical problem, but some of them, and especially social scientists, including psychologists look on tax evasion as an a social problem. In addition, various approaches to fight against tax evasion are being developed. Nevertheless in designing an anti-evasion policy it might seem dangerous to have to rely upon the consciences of potential evaders (Pyle, 1989, p.163). The main theoretical approaches to tax compliance have commonly been divided into the 'economic deterrence' approach, and the wider behavioural approach which incorporates both social and fiscal psychological approaches (Devos, 2014, p.14). Economists tend to see (construct) tax evasion as a technical problem; social scientists (including psychologists) as a social problem (Kirchler, 2009, p.28). The relevance of social norms is generally supported in empirical studies on tax evasion (Kirchler, 2009, p.193).

However, there were not so many studies in $\mathrm{BiH}$ about the tax evasion and its reflections on the humans and/or companies behaviour and vice versa, i.e. about link between tax evasion and socio-economic environment. As one of them, was study named „The Ethics of Tax Evasion: A Survey of Bosnian Opinion, (McGee, Bašić, Tyler, 2009, p.6). This study surveyed students at the University of Sarajevo in Bosnia and results indicate that the majority of respondents do not believe that tax evasion is ethical. The survey consisted of eighteen (18) statements. Using a seven-point Likert scale, respondents were asked to place the appropriate number in the space provided to indicate the extent of their agreement or disagreement with each statement (ibid, p.3). However, authors believe ethical attitude toward tax evasion is more complicated than that. Mentioned study showed that the strongest arguments justifying tax evasion occur in cases where the government was perceived as being corrupt or when the tax system was seen as unfair or when tax funds were spent on projects that the respondent does not approve of (ibid, p.6).

First, how do we measure the extent of evasion, given that it represents behaviour that by its very nature individuals and firms go to some length to hide? Second, how can we explain these patterns of behaviour, via theoretical, empirical, and experimental methods? Third, how can we use these various insights to control evasion? (Alm, 2012, p.2). These are just some of very important questions that many theorists and practitioners have tried to answer. However, the interaction between taxpayers and multiple jurisdictions necessarily gives rise to many questions under international law, and international taxation (Kerzner, Chodikoff, 2016, p.33).

Complete and precise definition of the term tax evasion, as a fiscal issue in many countries, is not easy and there is large number of definitions. Tax evasion - Deliberate acts to conceal income in order to escape tax liabilities (TADAT, Field Guide, 2015. p.87). The conceptual difference between tax evasion and legal tax avoidance depends on lawfulness of taxpayer's treatment. Each taxpayer endeavours to optimize his or her expenses, seeking every opportunity to legally reduce his or her tax liabilities. Tax avoidance - Practices by taxpayers to reduce tax liabilities by exploiting weaknesses in the law or through contrived schemes that push the boundaries of legal interpretation (TADAT, Field Guide, 2015. p.86).

It should be noted that the unemployment rate (registered unemployment) in $\mathrm{BiH}$ is high, that directly leads to strong and continuous encouragement for the grey labour market. The existence of "tax evasion" surely reduces public revenues, creating unfair competition among business entities and distorting the picture of the number of unemployed persons on the labour market. In our tax legislation there is no specific definition of terms tax evasion and tax avoidance and this study does not make a distinction between "tax evasion" and "tax avoidance" terms. In this regard, this paper says that it is necessary to emphasize and intensify the research efforts, content-oriented and rounded up in scientific and professional publications, in the sphere of tax evasion as an essential component, gaining a better understanding of the role and effect of the subjective and objective factors influencing it.

The paper is organized as follows. In section 1 first present the current tax procedures tax policy and economic-social environment of $\mathrm{BiH}$. In section 2 overview description of the sample and empirical data and analysis and presentation of research results on attitudes of respondents towards tax evasion in BiH. Conclude in section 3.

\section{The Current Tax Procedures, Tax Policy and Economic-Social Environment of Bosnia and Herzegovina}

In order to understand better the cause-and-effect relationships between tax evasion and the socio-economic system in, and within $\mathrm{BiH}$ or before the assumptions and results of the research conducted in this paper are presented, it is necessary to clarify the tax policy, the tax system and economic social situation within BiH. There is no uniform legal framework for the whole country of $\mathrm{BiH}$ to regulate the field of tax policy in form of a specific piece of legislation. The 
following constitutional acts govern the distribution of competences between different levels of governance in Bosnia and Herzegovina $(\mathrm{BiH})$ : the $\mathrm{BiH}$ Constitution, the Constitution of the Federation of $\mathrm{BiH}(\mathrm{FBiH})$, the Constitution of the Republic of Srpska (RS), and the Statute of the Brcko District (BD) of $\mathrm{BiH}$. In that sense, indirect taxation in $\mathrm{BiH}$ is within the competence of $\mathrm{BiH}$ institutions (in the entire territory of $\mathrm{BiH}$ ), whereas the direct taxation in $\mathrm{BiH}$ is within the competence of the $\mathrm{FBiH}$ (in its territory), of the RS (in its territory), and of the $\mathrm{BD}$ (in its territory).

The Law on the Indirect Taxation System in BiH (BiH ITS Law) (BiH OG, Nos. 44/03, 52/04, 34/07, 49/09 and 32/13) has created an institutional and organisational basis for establishing a single indirect taxation system in the entire territory of BiH. The BiH ITS Law also established the Indirect Taxation Authority (ITA) as the only institution competent for the implementation of regulations on indirect taxes and the policy defined by the Council of Ministers of $\mathrm{BiH}$. The ITA BiH is also competent for the collection and allocation of revenue from indirect taxes. For the purpose of this Law, the term "indirect tax" refers to import and export duties, excise duties, value added tax and any other tax levied on goods and services, including motor-fuel taxes. Indirect taxes were placed within the competence of the state and are almost completely harmonized with the European Union directives.

In the $\mathrm{FBiH}$, the $\mathrm{FBiH}$ Tax Administration (FBiH TA) is responsible for the implementation of legal provisions on taxation (direct taxes). The FBiH TA is part of the FBiH Ministry of Finance (FBiH MoF) and is the only body in the FBiH that is, inter alia, responsible for collection of direct taxes as stipulated by FBiH and cantonal laws. The work of the FBiH TA is regulated by the Law on the FBiH Tax Administration (FBiH TA Law) (FBIH OG, Nos. 28/04, 57/09, 40/10, 27/12, 7/13, 71/14 and 91/15), which stipulates its relevant competences and forms the basis for implementing all tax laws.

The field of transfer pricing in the FBiH is regulated by the Law on Corporate Income Tax (FBiH CIT Law) (FBiH OG, No. 15/16), Articles 44, 45 and 46, and by the Rulebook on Transfer Pricing (FBiH OG, No. 67/16). The FBiH CIT Law stipulates that taxpayers who take part in related-party transactions have to determine their taxable profit using a method which adheres to the arm's length principle.

The Republika Srpska Tax Administration (RSTA) is responsible for implementing all RS-level and certain local-level tax regulations in the RS. The work of the RSTA, taxation procedure and taxpayers' rights and obligations are regulated by the RS Law on Tax Procedure (RS TPL) (Republic of Srpska OG, Nos. 102/11, 108/11, 67/13, 31/14 and 44/16). The RSTA is also responsible for assessing tax liabilities pursuant to law, auditing the legality and regularity in applying tax legislation, including calculation and payment of direct taxes and interest (Republic of Srpska OG, Nos. 102/11, 108/11, 67/13, 31/14 and 44/16). The RS Law on Corporate Income Tax (RS CIT Law) (Republic of Srpska OG, No 94/15 and 1/17) regulates related-party transactions, i.e. transfer pricing rules, which in turn stipulate what is to be considered transfer price and related parties, methods for verifying transaction compliance with the arm's length principle, and required transfer pricing documentation.

In the Brcko District of $\mathrm{BiH}$, the implementation of taxation legal provisions (direct taxes) falls within the competence of the BDBiH Tax Administration (BDBiH TA). The BDBiH TA is part of the BDBiH Finance Directorate (BDBiH FD). The work of the BDBiH TA is regulated by the Law on the BDBiH Tax Administration (BDBiH TA Law) (BDBiH OG, Nos. 3/02, 42/04, 8/06, 3/07, 19/07, 2/08 and 6/13). From the above, one can comprehend the extraordinary complexity of the tax system of $\mathrm{BiH}$ and the difficulties encountered by all tax administrations within BiH. Speaking objectively, tax evasion and loss of tax revenue from transferring pricing pose a relatively low risk, mostly due to the low level of direct taxes in $\mathrm{BiH}$ (tax burden) or low number of major international companies as associated enterprises in $\mathrm{BiH}$ and companies operating abroad whose founders are $\mathrm{BiH}$ residents.

Economic situation in $\mathrm{BiH}$ during the post-war development is not impressive and events in the economic sphere are closely related to tax evasion. According to the World Bank (World Bank Business Doing Business Survey) for the year 2017, BiH was ranked as 81 st economy out of total 190 world economies. Doing Business ranking aggregates several different types of indicators, and one of them is "Paying taxes". Bosnia and Herzegovina's rank, which has been based on this indicator, is 131, the third lowest of 25 countries listed in Europe and Central Asia (we are only above Kyrgyzstan and Uzbekistan). ${ }^{1}$

The state is still dominant on the market in a form of public enterprises and companies. The general illiquidity and debts among all participants has taken such proportions that it threatens to completely stop the registered economic activity, doing business legally - the total number of blocked accounts, in the Register of transactional accounts of the Central Bank of Bosnia and Herzegovina, dated on 21st of July 2017, is $73.836 .{ }^{2}$. For transition countries, tax evasion is particularly acute and specific issue and that is the specificity of transition countries that Bosnia and Herzegovina

\footnotetext{
${ }^{1}$ www.doingbusiness.org/reports/reports/doing-business-2017, 22.06.2017.

${ }^{2}$ Central Banka of BiH, List of blocked accounts of legal entities, July 2017.
} 
belongs to ${ }^{3}$ the reason for that is its rate, extent and economic concequence that tax evasion leads to and which is visible in public in those countries. In post-war period $\mathrm{BiH}$ is characterized by transition towards modern market economy. Bosnia and Herzegovina, viewed through the prism of heritage, is atypical transition country with its surface of $51,197 \mathrm{~km} 2$ and according to the latest data there are around 3.8 million of inhabitants living on the territory of $\mathrm{BiH}$, small and open country with much more complex problems compared to other countries.

It is also characteristic for Western Balkan countries, as well as for $\mathrm{BiH}$, that they had and they still have experience that is significant during the transition process. $\mathrm{BiH}$ belongs to a group of transition countries where transition process was not successful; it is developing economy, with inherited socialist-economic system, with format of mixed market economy, with its specificities due to the war that had resulted in a devastated economy, destroyed economic structure and generally disrupted social relations. Revitalisation of economic business flows will be extremely difficult task and certainly of bigger and more significant challenge compared to other transition countries.

For $\mathrm{BiH}$ in current moment, in time of total social and economic transition with exceptionally high need for consolidation of public finances, due to the difficulties in determining the very beginning of transition and permanent political crisis and the economic crisis, it can be said in the beginning of transition period. The institutions' level of development is not at an enviable level, which can be seen particularly in the segment of information technologies where the process of electronic business is slow compared to other EU countries, as best illustrated by UN report on development of e-administration, according to which $\mathrm{BiH}$ was at the last place in the development of e-administration out of 43 European countries in $2016 .{ }^{4}$

It is quite certain that transition determination of $\mathrm{BiH}$ through its complexed and in large extent dysfunctional political system, with complexed institutional solutions, two autonomous entities have been established, Republic of Srpska (with two level of government, republic and local) and Federation of Bosnia and Herzegovina, (with three level of government, entity, cantonal and local) and Brcko District, Bosnia and Herzegovina still has institutional framework to respond to challenges of tax evasion.

\section{Description of the Sample and Empirical Data}

In this study, a statistically selected sample of 300 persons, where it was tried by the selected sample, it can be a sufficient indicator of the state of the studied subjects. Among the empirical characteristics of the respondents in the focus of interests are the taxpayers, and professional groups on one side of which is linked to the problem of tax evasion, and on the other hand, those professional groups that are related to this social problem, such as inspectors of taxes. The survey was conducted between September 2015 and June 2016, and at the end of June 2016 the target sample (N: 300) was collected when the data collection process was completed and access to the processed primary data was processed. In order to achieve the set goal, empirical research will focus on data collection both by taxpayers and tax administration employees. In accordance with the subject and the problem of research and the aims of empirical research in the sample on which two research groups or sub-groups have been investigated: 200 taxpayers (66.7\%) and 100 tax inspectors (33.3\%), whose attitudes, within further analysis and interpretation of data obtained by primary research, are comparable. By phase of field research, two groups of taxpayers are interviewed, by the nature of the "contradictory parties", the directors of companies or other responsible persons (Federation of Bosnia and Herzegovina, Republika Srpska and Brcko District of Bosnia and Herzegovina) who have intensive contacts with the tax administrations and employees in professional organizations (tax inspectors Indirect Taxation Authority BiH, tax inspectors Federation $\mathrm{BiH}$, tax inspectors Republika Srpska and tax inspectors Brcko District $\mathrm{BiH}$ ). For the purpose of conducting the research, a comprehensive questionnaire was produced, representative and appropriate, which constitutes a strong initiative for further investigation of the phenomenon of tax evasion.

The survey questionnaire used to collect primary data consists of several sets and over 50 questions. Structured and unstructured questions with a scale for general attitude tests towards occurrence of tax evasion in the country and society have been used for measuring, Scale for "measuring" the general (un)satisfaction with things and phenomena on tax evasion and the Scale for testing attitudes towards priorities for decreasing and determining the occurrence of tax evasion. Set of questions included issues in connection with the attitude of respondents and the degree to which they agree with tax evasion, how satisfied they are with occurrences that are affecting tax evasion and what they consider to be an important priority in removing obstacles. The question was also raised about the rate of tax evasion in Bosnia and Herzegovina (in percentages), of total tax revenues.

The questionnaire consisted of various claims and questions with the offered intensity responses. Respondents had to indicate the degree of agreement or disagreement with the stated claims, where the degree of agreement with individual

\footnotetext{
${ }^{3}$ https://www.cia.gov/library/publications/resources/the-world-factbook/geos/bk.html, June 2017.

${ }^{4}$ For more details about the development index of e-administration refer to the link: https://publicadministration.un.org.
} 
statements was measured by the Likert type scale. The offered intensity varied in one or two directions, from insufficient to excellent or neutral to maximum satisfaction on one side or maximum dissatisfaction on the other. Stage scales and possible responses ranged from 1 to 5 .

Within this comprehensive study, number of respondents (N:300) is heterogeneous due to the study sample, many analysis and various statistical methods have been applied to look at the detailed characteristics of the observed variables (methods of descriptive statistic, structural analysis and "crossing", correlation analysis, hi-square test).

Correlation analysis has been performed using Spearman's correlation coefficient of the descriptive statistic rank. Spearman's correlation coefficient rank is used to check if there is interdependence between the variables (with ordinal categorical variables or if the presumption of "normality" has not been satisfied). The correlation is significant for the first type error 0.05 (two-way), if the p value of correlation coefficient is less than 0.05 .

The following tests were also used:

$\checkmark$ Shapiro - Wilk (SW) ${ }^{5}$ and Kolmongor-Smirn test ${ }^{6}$, to check if the distribution of analysed variable satisfy presumption of "normality" for samples with small or large number of observations,

$\checkmark$ Mann-Whitney U test, for two independent samples, for distributions that do not satisfy presumption of "normality",

$\checkmark \quad \mathrm{Z}$ test, differences of two proportions.

\subsection{Analysis and Presentation of Research Results on Attitudes of Respondents Towards Tax Evasion}

Based on acquired theoretical and empirical findings on the characteristics of tax evasion, the hypothesis of this paper is: H1. The level of tax evasion is in direct correlation with the economic well-being of society, the social and economic environment.

Previous considerations unambigously point out to the great importance of tax evasion and the key topic of this research, and the dependant variable in models that will be created for checking of the main and auxiliary hypothesis is tax evasion. With regard to the unit of measurement, this variable is metric, however answers have been found in questionaire through intervals so it can be observed as an ordinal or possibly through middle of intervals as interruption variable. In this paper, the intention was to present the analysis, identification and indicator of the current state of tax evasion rate in Bosnia and Herzegovina by which it could be possible to provide appropriate preventive and corrective measures.

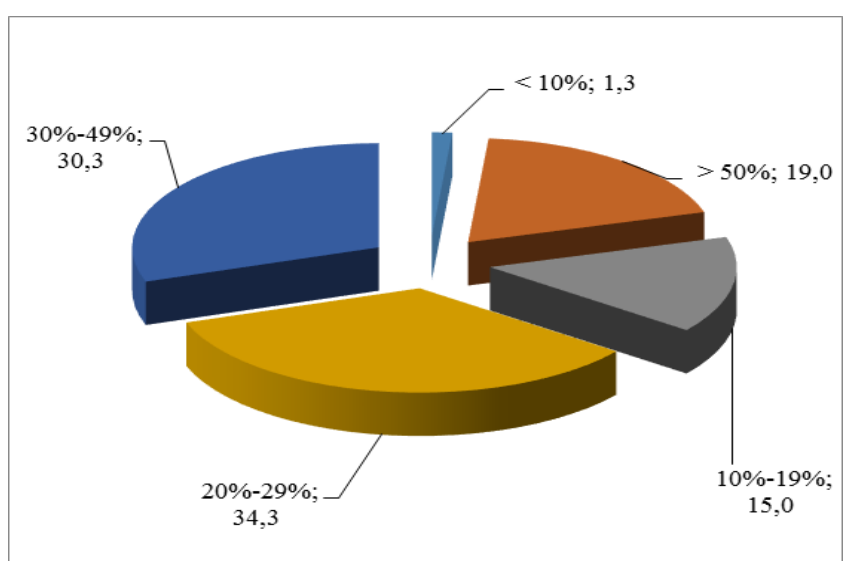

Figure 1. Structure of variable, tendency and rate of tax evasion in Bosnia and Herzegovina in sample and sub-samples The tax evasion rate in the questionsire is divided in intervals: $<10 \%, 10 \%-19 \%, 20 \%-29 \%, 30 \%-49 \%$ and $>50 \%$. The biggest part of respondents (about 50\%) who consider that tax evasion is present in the level higher than $40 \%$ of the total

\footnotetext{
${ }^{5}$ Shapiro - Wilk (SW) test is used in order to check whether in samples, which are on our disposal, the distribution of analyzed occurrence is satisfying presumption of normality (sample of the size less than 50 elements). P-value with appropriate SW test is considered as statistically important or significant if it is lower than 0.05 , given that tests are being performed with the first type error $5 \%$, i.e. with significance $95 \%$. In that case, the hypothesis that distribution of analyzed occurrence does not meet presumption of "normality" is accepted.

${ }^{6}$ Kolmongor - Smirn test is used in order to check whether in samples, which are on our disposal, the distribution of analyzed occurrence is satisfying presumption of normality (sample of the size of 50 or more elements). P-value with appropriate KS test is considered as statistically important or significant if it is lower than 0.05 , given that tests are being performed with the first type error $5 \%$, i.e. with significance $95 \%$.
} 
tax revenues, while $34.33 \%$ of respondents consider the level of evasion to be within the interval of $20-29 \%$. This alarming response indicates that it is necessary to initiate changes and to perform activities in the shortest possible period if Bosnia and Herzegovina wants to reduce the level of tax evasion. Also in sub-samples, the situation is very similar according to interests, so there is no statistically significant difference between sub-samples according to this opinion (table 1 , hi-square empirical $=3.616, \mathrm{p}$ value $=0.460>0.05$ ). For a more objective conclusion on tax evasion rate in Bosnia and Herzegovina, i.e. to find out whether it was higher or lower, there should be more inputs. However, it should be said that this data from (figure 1) has just a relative or aproximate value because it gives data provided by respondent.

Table 1. Tax evasion rate in Bosnia and Herzegovina in sample and sub-samples, cross-tabulation

\begin{tabular}{|c|c|c|c|c|c|c|c|}
\hline & & \multicolumn{4}{|c|}{ Sub-sample } & \multirow{2}{*}{\multicolumn{2}{|c|}{$\sum$}} \\
\hline & & \multicolumn{2}{|c|}{ Tax payers } & \multicolumn{2}{|c|}{ Inspectors } & & \\
\hline & & $\begin{array}{l}\text { Number of } \\
\text { respondents }\end{array}$ & $\begin{array}{l}\text { Expected } \\
\text { number of } \\
\text { respondents }\end{array}$ & $\begin{array}{l}\text { Number of } \\
\text { respondents }\end{array}$ & $\begin{array}{l}\text { Expected } \\
\text { number of } \\
\text { respondents }\end{array}$ & $\mathrm{N}$ & $\begin{array}{l}\text { Expected } \\
\text { number of } \\
\text { respondents }\end{array}$ \\
\hline \multirow{8}{*}{$\begin{array}{l}\text { 6. Tax evasion } \\
\text { rate in } \mathrm{BiH}\end{array}$} & $<10 \%$ & 4 & 2,7 & 0 & 1,3 & 4 & 4 \\
\hline & $10 \%-$ & 39 & 38 & 18 & 19 & 57 & 57 \\
\hline & $19 \%$ & & & & & & \\
\hline & $20 \%-$ & 28 & 30 & 17 & 15 & 45 & 45 \\
\hline & $29 \%$ & & & & & & \\
\hline & $30 \%-$ & 65 & 68,7 & 38 & 34,3 & 103 & 103 \\
\hline & $49 \%$ & & & & & & \\
\hline & $>50 \%$ & 64 & 60,7 & 27 & 30,3 & 91 & 91 \\
\hline \multicolumn{2}{|l|}{$\sum$} & 200 & 200 & 100 & 100 & 300 & 300 \\
\hline
\end{tabular}

Table 2. Tax evasion rate in $\mathrm{BIH}$, cross-tabulation with the sex of respondents

\begin{tabular}{|c|c|c|c|c|c|c|c|}
\hline & & \multicolumn{4}{|c|}{ sex } & \multirow{2}{*}{\multicolumn{2}{|c|}{$\sum$}} \\
\hline & & \multicolumn{2}{|c|}{ male } & \multicolumn{2}{|c|}{ female } & & \\
\hline & & $\begin{array}{l}\text { Number of } \\
\text { respondents }\end{array}$ & $\begin{array}{l}\text { Expected } \\
\text { number of } \\
\text { respondents }\end{array}$ & $\begin{array}{l}\text { Number of } \\
\text { respondents }\end{array}$ & $\begin{array}{l}\text { Expected } \\
\text { number of } \\
\text { respondents }\end{array}$ & $\mathrm{N}$ & $\begin{array}{l}\text { Expected } \\
\text { number of } \\
\text { respondents }\end{array}$ \\
\hline \multirow{5}{*}{$\begin{array}{l}\text { 6. Tax } \\
\text { evasion rate } \\
\text { in } \mathrm{BiH}\end{array}$} & $<10 \%$ & 4 & 1,9 & 0 & 2,1 & 4 & 4 \\
\hline & $\begin{array}{l}10 \% \\
19 \%\end{array}$ & -23 & 26,4 & 34 & 30,6 & 57 & 57 \\
\hline & $\begin{array}{l}20 \% \\
29 \%\end{array}$ & -24 & 20,9 & 21 & 24,2 & 45 & 45 \\
\hline & $\begin{array}{l}30 \% \\
49 \%\end{array}$ & -54 & 47,7 & 49 & 55,3 & 103 & 103 \\
\hline & $>50 \%$ & 34 & 42,2 & 57 & 48,8 & 91 & 91 \\
\hline$\sum$ & & 139 & 139 & 161 & 161 & 300 & 300 \\
\hline
\end{tabular}

There is statistically significant difference between groups classified by sex (hi-square empircal $=10.824, p$ value $=0.029$ $<0.05$ ). Difference between groups classified by level of education (hi-square empircal $=4.532, \mathrm{p}$ value $=0.806>0.05$ ) and work experience (hi-square empircal $=15.781, \mathrm{p}$ vrijednost $=0.468>0.05$ ) are not recorded as statistically significant.

If we observe tax evasion as an interuption variable where modalities are middle of provided intervals, we can calculate indicators of descriptive statistic in sample and sub-sumples (table 3). 
Table 3. Descriptive statistic of the degree of presence of tax evasion in Bosnia and Herzegovina in sample and sub-samples

\begin{tabular}{|c|c|c|c|c|c|c|c|}
\hline & $\mathrm{N}$ & Minimum & Maximum & Average & Median & $\begin{array}{l}\text { Standard } \\
\text { deviation }\end{array}$ & \\
\hline \multirow[t]{3}{*}{ sample } & 300 & 5 & 75 & 37,28 & 25 & 20,349 & Mann-Whitney U $=9489,000$ \\
\hline & & & & & & & Wilcoxon $\mathrm{W}=14539,000$ \\
\hline & & & & & & & $\bar{Z}=-0,752$ \\
\hline Tax payers & 200 & 5 & 75 & 37,75 & 40 & 20,519 & $\begin{array}{l}\mathrm{P} \text { value }=0,452>0,05 \text { difference } \\
\text { between payers and inspectors about } \\
\text { estimation of tax evasion rate in } \mathrm{BiH} \text { is } \\
\text { not statistically significant }\end{array}$ \\
\hline Inspectors & 100 & 15 & 75 & 36,35 & 25 & 20,074 & \\
\hline
\end{tabular}

Hypothesis of this paper is that tax evasion is in direct correlation with economic welfare of sociaty, social environment and economic activity. To check this hypothesis, we will calculate correlation coeficients rank between variables of tax evasion rates as ordinal variables and variables that are expressing the economic welfare of a society, social environment and economic activity, data from table number (5.4. Improvments of economic work conditions, 5.5. Arangement of social benefits and securities, 5.6. Arrangements of informal sector). In (table 4), correlation coeficients have been presented. Using the hi-square test of interdependence, test whether there is a connection between two variables, but in those cases there is a significant difference between the correlation account and the result of the hi-square test, because the correlation account shows the degree of connection between the two variables, while the hi-square test shows the probability this is the significance of connection. A significant modification to the Pearson's $\chi 2$ test was introduced by Fisher in (1922) (the degree of freedom was decreased by one unit when applied to contingency tables). Another correction made by Fisher took into account the number of unknown parameters associated to the theoretical distribution, when the parameters are estimated from central moments (Fisher, 1924).

We will also perform cross-tabulations with original variable for tax evasion rate and hi-square tests of interdependence ${ }^{7}$ with regards to variables that are expressing the economic welfare of society, social environment and economic activity (table 5 (5.1, 5.2 i 5.3.).

Table 4. Correlation matrix for coefficients of correlation between rank variables of tax evasion as ordinal variables and variables expressing economic welfare of society, social environment and economic activity.

\begin{tabular}{lllll}
\hline Spearman's rho & & sample & tax payers & inspectors \\
\hline Improvement of economic conditions for work & Correlation coefficient & 0,168 & 0,146 & 0,195 \\
\cline { 2 - 5 } & $\mathrm{P}$ value & 0,004 & 0,039 & 0,052 \\
\cline { 2 - 5 } & $\mathrm{N}$ & 300 & 200 & 100 \\
\hline Arranging Social Welfare and Security & Correlation coefficient & 0,169 & 0,151 & 0,187 \\
\hline & $\mathrm{P}$ value & 0,003 & 0,033 & 0,062 \\
\cline { 2 - 5 } & $\mathrm{N}$ & 300 & 200 & 100 \\
\hline Arranging the informal sector & Correlation coefficient & 0,191 & 0,193 & 0,192 \\
\cline { 2 - 5 } & $\mathrm{P}$ value & 0,001 & 0,006 & 0,056 \\
\cline { 2 - 5 } & $\mathrm{N}$ & 300 & 200 & 100 \\
\hline
\end{tabular}

Correlation analysis was performed using Spearman's correlation coefcient rank $^{8}$ and in both the complete sample and the payer's sample the direct significant correlation has been confirmed between variable of tax evasion rates as an ordinal variable and variables that are expressing economic welfare of society, social environment and economic activity (bolded values in the table 4., as they are significant correlation coeficients if $p$ value is lower than 0.05 ) However, it is not the case with the inspector's sub-sample.

\footnotetext{
${ }^{7}$ If $X$ and $Y$ are two categorical variables, the goal of hi-square test of interdependence is to check whether those two variables are (in)dependent. Using the hi-square test of interdependence, we are testing whether there is correlation betweeen the two variables, but in those cases there is an important difference between correlation calculation and the result of hi-square test, as the correlation calculation indicates to us the degree of correlation between the two variables, while the hi-square test indicates probability, i.e. significance of correlation.

${ }^{8}$ Spearman's correlation coeficient rank is used in order to check whether there is interdependence between variables (with ordinal categorical variables or if the presumption of "normality“ is not satisfied). Correlation is significant for the first type error 0.05 (two-ways), if p value of correlation coeficient is less than 0.05 .
} 
Table 5. (5.1-5.3) Cross tabulations and the results of the hi-square test of the interdependence of the original variable for the amount of tax evasion in relation to the variables expressing economic welfare of society, social environment and economic activity (1. unimportant, 5. very important)

\begin{tabular}{|c|c|c|c|c|c|c|c|c|}
\hline & & & \multicolumn{5}{|c|}{ 5.1. Improvement of economic conditions for work } & \multirow[t]{2}{*}{ Total } \\
\hline & & & 1 & 2 & 3 & 4 & 5 & \\
\hline \multirow{10}{*}{$\begin{array}{l}\text { Which is the amount of } \\
\text { tax evasion in Bosnia } \\
\text { and Herzegovina in } \\
\text { percentages of total tax } \\
\text { revenues? }\end{array}$} & \multirow[t]{2}{*}{$<10 \%$} & Count & 1 & 0 & 0 & 0 & 3 & 4 \\
\hline & & Expected & 0,1 & 0,3 & 1,1 & 1,3 & 1,2 & 4 \\
\hline & \multirow[t]{2}{*}{$>50 \%$} & Count & 1 & 0 & 15 & 21 & 20 & 57 \\
\hline & & Expected & 1,1 & 3,6 & 16,2 & 18,6 & 17,5 & 57 \\
\hline & \multirow[t]{2}{*}{$10 \%-19 \%$} & Count & 0 & 8 & 18 & 11 & 8 & 45 \\
\hline & & Expected & 0,9 & 2,9 & 12,8 & 14,7 & 13,8 & 45 \\
\hline & \multirow[t]{2}{*}{$20 \%-29 \%$} & Count & 3 & 9 & 29 & 29 & 33 & 103 \\
\hline & & Expected & 2,1 & 6,5 & 29,2 & 33,6 & 31,6 & 103 \\
\hline & \multirow[t]{2}{*}{$30 \%-49 \%$} & Count & 1 & 2 & 23 & 37 & 28 & 91 \\
\hline & & Expected & 1,8 & 5,8 & 25,8 & 29,7 & 27,9 & 91 \\
\hline \multirow{2}{*}{\multicolumn{2}{|c|}{$\sum$}} & $\mathrm{N}$ & 6 & 19 & 85 & 98 & 92 & 300 \\
\hline & & Expected & 6 & 19 & 85 & 98 & 92 & 300 \\
\hline \multicolumn{9}{|l|}{ hi-square value $=42,933$} \\
\hline \multicolumn{9}{|c|}{$\begin{array}{l}\mathrm{P} \text { value }=0,000<0,05 \mathrm{P} \text { there is a significant correlation between the amount of tax evasion and the variables that reflect the economic well-being } 0 \\
\text { society, the social environment and economic activity }\end{array}$} \\
\hline & & & \multicolumn{5}{|c|}{ 5.2. Arranging Social Welfare and Security } & \multirow[t]{2}{*}{$\bar{\sum}$} \\
\hline & & & 1 & 2 & 3 & 4 & 5 & \\
\hline \multirow{10}{*}{$\begin{array}{l}\text { Which is the amount of } \\
\text { tax evasion in Bosnia } \\
\text { and Herzegovina in } \\
\text { percentages of total tax } \\
\text { revenues? }\end{array}$} & \multirow[t]{2}{*}{$<10 \%$} & Count & 1 & 0 & 0 & 1 & 2 & 4 \\
\hline & & Expected & 0,1 & 0,4 & 1,2 & 1,5 & 0,7 & 4 \\
\hline & \multirow[t]{2}{*}{$>50 \%$} & Count & 2 & 4 & 14 & 26 & 11 & 57 \\
\hline & & Expected & 1,5 & 6,3 & 17,1 & 21,5 & 10,6 & 57 \\
\hline & \multirow[t]{2}{*}{$10 \%-19 \%$} & Real & 1 & 10 & 17 & 9 & 8 & 45 \\
\hline & & Expected & 1,2 & 5 & 13,5 & 17 & 8,4 & 45 \\
\hline & \multirow[t]{2}{*}{$20 \%-29 \%$} & Count & 3 & 18 & 30 & 36 & 16 & 103 \\
\hline & & Expected & 2,7 & 11,3 & 30,9 & 38,8 & 19,2 & 103 \\
\hline & \multirow[t]{2}{*}{$30 \%-49 \%$} & Real & 1 & 1 & 29 & 41 & 19 & 91 \\
\hline & & Count & 2,4 & 10 & 27,3 & 34,3 & 17 & 91 \\
\hline \multirow{2}{*}{\multicolumn{2}{|c|}{$\sum$}} & $\mathrm{N}$ & 8 & 33 & 90 & 113 & 56 & 300 \\
\hline & & Expected & 8 & 33 & 90 & 113 & 56 & 300 \\
\hline \multicolumn{9}{|l|}{ hi-square value $=39,071$} \\
\hline $\begin{array}{l}\mathrm{P} \text { value }=0,001<0,05 \\
\text { society, the social envir }\end{array}$ & $\begin{array}{l}\text { there is a si } \\
\text { iment and e }\end{array}$ & $\begin{array}{l}\text { correlation } \\
\text { activity }\end{array}$ & in the & of tax & in and & ariable & the ec & ll-being \\
\hline & & & 5.3. & ng the & al sect & & & $\bar{\sum}$ \\
\hline & & & 1 & 2 & 3 & 4 & 5 & \\
\hline Which is the amount of & $<10 \%$ & Count & 1 & 0 & 1 & 1 & 1 & 4 \\
\hline tax evasion in Bosnia & & Expected & 0,2 & 0,9 & 1,7 & 0,8 & 0,3 & 4 \\
\hline and Herzegovina in & $>50 \%$ & Count & 1 & 9 & 19 & 19 & 9 & 57 \\
\hline percentages of total tax & & Expected & 3 & 12,5 & 24,7 & 12 & 4,8 & 57 \\
\hline revenues? & $10 \%-19 \%$ & Count & 2 & 15 & 19 & 7 & 2 & 45 \\
\hline & & Expected & 2,4 & 9,9 & 19,5 & 9,5 & 3,8 & 45 \\
\hline & $20 \%-29 \%$ & Count & 5 & 26 & 50 & 15 & 7 & 103 \\
\hline & & Expected & 5,5 & 22,7 & 44,6 & 21,6 & 8,6 & 103 \\
\hline & $30 \%-49 \%$ & Count & 7 & 16 & 41 & 21 & 6 & 91 \\
\hline & & Expected & 4,9 & 20 & 39,4 & 19,1 & 7,6 & 91 \\
\hline$\sum$ & & $\mathrm{N}$ & 16 & 66 & 130 & 63 & 25 & 300 \\
\hline & & Expected & 16 & 66 & 130 & 63 & 25 & 300 \\
\hline hi-square value $=27,07$ & & & & & & & & \\
\hline
\end{tabular}

Table 6. Results for hi-square tests of the interdependence of the original variable for the amount of tax evasion in relation to the variables expressing economic welfare of society, social environment and economic activity

\begin{tabular}{lllll}
\hline & Tax payers & & Inspectors \\
\hline & hi-square & $\mathrm{p}$ value & hi-square & $\mathrm{p}$ value \\
\hline Improvement of economic conditions for work & 36,041 & 0,003 & 18,116 & 0,112 \\
\hline Arranging Social Welfare and Security & 26,559 & 0,047 & 19,087 & 0,086 \\
\hline Arranging the informal sector & 26,378 & 0,049 & 8,916 & 0,71 \\
\hline Arranging the informal sector & 26,378 & 0,049 & 8,916 & 0,71 \\
\hline
\end{tabular}


In the complete sample and sample of the taxpayer, and the hi-square interdependency test, confirmed the correlation between the variables of tax evasion as an ordinal variable and variables in relation to the variables expressing economic welfare of society, social environment and economic activity ( $\mathrm{p}$ value in table 5. (5.1-5.3) and 6. because the significance of the variable is significant if the $\mathrm{p}$ value is lower than 0.05 ). However, this is not the case in the inspector's. It is obvious that in this matter the formation of the inspector's position was dominantly a personal experience. This is a partially confirmed hypothesis H1. The level of tax evasion is in direct correlation with the economic well-being of society, the social and economic environment. We know now a lot more about tax evasion and compliance, we are far away from knowing it all. Further research is required (Pickhardt, Prinz, 2013, p.14).

Below we will analyse the correlation coeficient rank between variable of tax evasion rates as ordinal variable and variables about the atitude towards tax evasion, satisfaction of respondents and priorities in removing obstacles in fighting against tax evasion.

Bolded correlation coefficients in (table 7.) are statistically significant and positive. It is apparent from the things mentioned that, according to the rate of significant correlation coeficients rank, we can make ranking list of statements expressing the attitude towards tax evasion, satisfaction of respondents and priorities in removing obstacles in fighting against tax evasion within the context of their impact to tax evasion rate:

- 1.1. Tax evasion represents the biggest brake in development of a society.

- 1.11. Tax payers who did not commit tax evasion are rare.

- 1.5. Tax evasion fines/sanctions are disproportionate and inefficient and should be a lot stricter.

- 5.6. Arrengement of informal sector.

- 5.3. Change and improvement of tax regulations.

- 5.1. Improvement of system of control and collection of taxes.

- 5.5. Arrangement of social benefits and security.

- 5.4. Improvement of economic work conditions.

- 1.2. Persons in „high positions“ do not adhere to standards in society.

- 1.7. Tax evasion is an important indicator of system value drop.

- 1.4. Only people who are not directly responsible for suppression of evasion are talking negatively about the evasion.

- 1.12. Tax evasion is traditionally characteristic for our mentality.

- 1.13. Reason for tax evasion is low level of education.

In general, we can conclude that, based on results of research and based on casual links of al factors, the priority should be given to those factors that will in quicker and more efficient way improve the state with certain measures and activities. Measures that are leading to improvements of those indicators that have higher correlation coeficient should be of higher priority. 
Table 7. Correlation matrix for correlation coefficients rank between variable of tax evasion rate as ordinal variable and variables that are expressing the attitude towards tax evasion, satisfaction of respondents and priorities in removing obstacles in fighting against tax evasion

\begin{tabular}{|c|c|c|}
\hline Spearman's rho & & Tax evasion \\
\hline \multirow{2}{*}{ 1.1. Tax evasion represents the biggest brake in development of a society } & Correlation coeficient & 0,286 \\
\hline & $\mathrm{P}$ value & 0 \\
\hline 1.2. Persons in ,high positions" do not adhere to standards in society & Correlation coeficient & 0,161 \\
\hline \multirow[t]{2}{*}{ 1.3. Tax evasion is equaly present in all countries } & Correlation coeficient & 0,066 \\
\hline & P value & 0,252 \\
\hline $\begin{array}{l}\text { 1.4. Only people who are not directly responsible for suppression of evasion are talking } \\
\text { negatively about the evasion }\end{array}$ & Correlation coeficient & 0,126 \\
\hline \multirow[t]{2}{*}{ 1.5. Tax evasion fines/sanctions are disproportionate and inefficient and should be a lot stricter } & Correlation coeficient & 0,245 \\
\hline & $\mathrm{P}$ value & 0 \\
\hline \multirow[t]{2}{*}{ 1.6. Tax evasion is in the most cases unprovable } & Correlation coeficient & $-0,007$ \\
\hline & $\mathrm{P}$ value & 0,898 \\
\hline \multirow[t]{2}{*}{ 1.7. Tax evasion is an important indicator of system value drop } & Correlation coeficient & 0,131 \\
\hline & $\mathrm{P}$ value & 0,023 \\
\hline 1.8. Low level od personal incomes affects the tax evasion rate & Correlation coeficient & $-0,021$ \\
\hline 1.9. Tax evasion is common occurrence for countries in transition & P value & 0,447 \\
\hline \multirow{2}{*}{ 1.10. Media exaggerate when pointing out at harmfulness of tax evasion } & Correlation coeficient & $-0,064$ \\
\hline & $\mathrm{P}$ value & 0,271 \\
\hline \multirow[t]{2}{*}{ 1.11. Tax payers who did not commit tax evasion are rare } & Correlation coeficient & 0,27 \\
\hline & $\mathrm{P}$ value & 0 \\
\hline \multirow{2}{*}{ 1.12. Tax evasion is traditionally characteristic for our mentality } & Correlation coeficient & 0,093 \\
\hline & $\mathrm{P}$ value & 0,107 \\
\hline \multirow[t]{2}{*}{ 1.13. Reason for tax evasion is low level of education } & Correlation coeficient & $-0,006$ \\
\hline & P value & 0,922 \\
\hline \multirow[t]{2}{*}{ 3.1. By overal social relation towards tax evasion } & Correlation coeficient & $-0,002$ \\
\hline & P value & 0,973 \\
\hline \multirow[t]{2}{*}{ 3.2. By degree to which the public opinion on tax evasion has been developed } & Correlation coeficient & $-0,005$ \\
\hline & P value & 0,93 \\
\hline \multirow[t]{2}{*}{ 3.3. By work and organization of tax administrations (TA ITA; TA RS; TA FBIH; TA BDBIH) } & Correlation coeficient & $-0,083$ \\
\hline & $\mathrm{P}$ value & 0,15 \\
\hline 3.5. By possibility to get information about work of those who are responsible & Correlation coeficient & $-0,06$ \\
\hline & P value & 0,298 \\
\hline 3.6. By own professional development & Correlation coeficient & $-0,019$ \\
\hline & $\mathrm{P}$ value & 0,748 \\
\hline 3.7. Tax laws and regulations are too complicated & Correlation coeficient & 0,019 \\
\hline & P value & 0,742 \\
\hline 3.8. By general economic situation and conditionsn for ensuring the egzistency from work & Correlation coeficient & $-0,032$ \\
\hline & P value & 0,583 \\
\hline 3.9. By general culture about the need for paying taxes & Correlation coeficient & $-0,025$ \\
\hline & P value & 0,663 \\
\hline 3.10. Collected taxes are spent in an irrational way by state & Correlation coeficient & $-0,09$ \\
\hline & P value & 0,12 \\
\hline 3.11. Rate of tax burden & Correlation coeficient & 0,083 \\
\hline & P value & 0,152 \\
\hline 5.1. Improvement of system of control and collection of taxes & Correlation coeficient & 0,181 \\
\hline & P value & 0,002 \\
\hline 5.2. Building moral standards about the need to pay taxes & Correlation coeficient & 0,108 \\
\hline & P value & 0,061 \\
\hline 5.3.Change and improvement of tax regulations & Correlation coeficient & 0,189 \\
\hline & P value & 0,001 \\
\hline 5.4. Improvement of economic work conditions & Correlation coeficient & 0,168 \\
\hline & $\mathrm{P}$ value & 0,004 \\
\hline 5.5. Arrangement of social benefits and security & Correlation coeficient & 0,169 \\
\hline & $\mathrm{P}$ value & 0,003 \\
\hline 5.6. Arrangement of informal sector & Correlation coeficient & 0,191 \\
\hline & $\mathrm{P}$ value & 0,001 \\
\hline
\end{tabular}




\section{Conclusion}

This paper is an attempt to analyze tax evasion from a side that was poorly illuminated so far in Bosnia and Herzegovina, and the intention was to show the analysis, identification and indicator of the current tax evasion rate, by which some preventive and corrective measures could be provided.

The paper explored and confirmed the thesis that tax evasion rate is in direct correlation with economic welfare of society, social environment and economic activity. No progress can be expected with respect to the reduction of tax evasion if the environment itself does not improve.

Bosnia and Herzegovina as transition country is subject to any form of tax evasion. For this reason it is important to understand the essence of the problem, to ensure integration of existing tax capacities, harmonize the law framework with the aim of eliminating system barriers and create unique approach that will fit into economic, political and legal system of the state. The lack of appropriate legal framework may have a number of adverse consequences, primarily for taxpayers and therefore the quick intervention and multi-institutional approach is required in order to address this problem. A complex and changing business environment, as well as changes within the environment of taxpayers themselves, open possibilities and exposure to the risk for occurrence of tax evasion. The overall state of the economy of one state, macroeconomic environment (economic movements) and institutional system of one country represent one of the broadest factors that affect the tax evasion. Events in economic sphere are in close correlation with taxation, and it also has synergetic effect to the overall economy.

\section{Appendix 1}

Correlations matrix for coefficients of correlation between rank variables, sample (Table 4.)

\begin{tabular}{|c|c|c|c|c|}
\hline & $\begin{array}{l}\text { Improvement of } \\
\text { economic conditions } \\
\text { for work }\end{array}$ & $\begin{array}{l}\text { Arranging Social } \\
\text { Welfare and } \\
\text { Security }\end{array}$ & $\begin{array}{l}\text { Arranging the } \\
\text { informal sector }\end{array}$ & $\begin{array}{l}\text { Tax evasion } \\
\text { rang }\end{array}$ \\
\hline Correlation Coefficient & 1.000 &, $531^{* *}$ &, $351^{* *}$ &, $168^{* *}$ \\
\hline Sig. (2-tailed) & . & .000 & .000 & .004 \\
\hline $\mathrm{N}$ & 300 & 300 & 300 & 300 \\
\hline Correlation Coefficient &, $531^{* *}$ & 1.000 & $419^{* *}$ & $169^{* *}$ \\
\hline Sig. (2-tailed) & .000 &. & .000 & .003 \\
\hline $\mathrm{N}$ & 300 & 300 & 300 & 300 \\
\hline Correlation Coefficient &, $351^{* *}$ & $419^{* *}$ & 1.000 &, $191^{* *}$ \\
\hline Sig. (2-tailed) & .000 & .000 & . & .001 \\
\hline $\mathrm{N}$ & 300 & 300 & 300 & 300 \\
\hline Correlation Coefficient &, $168^{* *}$ &, $169^{* *}$ &, $191^{* *}$ & 1.000 \\
\hline Sig. (2-tailed) & .004 & .003 & .001 & . \\
\hline $\mathrm{N}$ & 300 & 300 & 300 & 300 \\
\hline
\end{tabular}




\section{Appendix 2}

Correlations matrix for coefficients of correlation between rank variables, taxpayers and inspectors (Table 4.)

\begin{tabular}{|c|c|c|c|c|c|}
\hline \multicolumn{2}{|c|}{ Subsample (Tax payers/Inspectors) } & \multirow{2}{*}{$\begin{array}{l}\text { Improvement of } \\
\text { economic } \\
\text { conditions for work } \\
1.000\end{array}$} & \multirow{2}{*}{$\begin{array}{l}\text { Arranging } \\
\text { Social Welfare } \\
\text { and Security } \\
571^{* *}\end{array}$} & \multirow{2}{*}{$\begin{array}{l}\text { Arranging the } \\
\text { informal sector }\end{array}$} & \multirow{2}{*}{$\begin{array}{l}\text { Tax } \\
\text { evasion } \\
\text { rang } \\
146^{*}\end{array}$} \\
\hline $\begin{array}{ll}\text { Improvement } & \text { of } \\
\text { economic conditions for }\end{array}$ & $\begin{array}{l}\text { Correlation } \\
\text { Coefficient }\end{array}$ & & & & \\
\hline & Sig. (2-tailed) & . & .000 & .000 & .039 \\
\hline & $\mathrm{N}$ & 200 & 200 & 200 & 200 \\
\hline \multirow[t]{3}{*}{$\begin{array}{l}\text { Arranging Social Welfare } \\
\text { and Security }\end{array}$} & $\begin{array}{l}\text { Correlation } \\
\text { Coefficient }\end{array}$ &, $571^{* *}$ & 1.000 &, $430^{* *}$ &, $151^{*}$ \\
\hline & Sig. (2-tailed) & .000 & . & .000 & .033 \\
\hline & $\overline{\mathrm{N}}$ & 200 & 200 & 200 & 200 \\
\hline \multirow[t]{3}{*}{$\begin{array}{l}\text { Arranging the informal } \\
\text { sector }\end{array}$} & $\begin{array}{l}\text { Correlation } \\
\text { Coefficient }\end{array}$ &, $385^{* *}$ &, $430^{* *}$ & 1.000 &, $193^{* *}$ \\
\hline & Sig. (2-tailed) & .000 & .000 & . & .006 \\
\hline & $\mathrm{N}$ & 200 & 200 & 200 & 200 \\
\hline \multirow[t]{3}{*}{ Tax evasion rang } & $\begin{array}{l}\text { Correlation } \\
\text { Coefficient }\end{array}$ &, $146^{*}$ &, $151^{*}$ &, $193^{* *}$ & 1.000 \\
\hline & Sig. (2-tailed) & .039 & .033 & .006 & . \\
\hline & $\overline{\mathrm{N}}$ & 200 & 200 & 200 & 200 \\
\hline \multirow{3}{*}{$\begin{array}{l}\text { Improvement } \\
\text { economic conditions for } \\
\text { work }\end{array}$} & $\begin{array}{l}\text { Correlation } \\
\text { Coefficient }\end{array}$ & 1.000 &, $424^{* *}$ &, $262^{* *}$ & .195 \\
\hline & Sig. (2-tailed) & . & .000 & .008 & .052 \\
\hline & $\mathrm{N}$ & 100 & 100 & 100 & 100 \\
\hline \multirow[t]{3}{*}{$\begin{array}{l}\text { Arranging Social Welfare } \\
\text { and Security }\end{array}$} & $\begin{array}{l}\text { Correlation } \\
\text { Coefficient }\end{array}$ &, $424^{* * *}$ & 1.000 &, $350^{* *}$ & .187 \\
\hline & Sig. (2-tailed) & .000 & . & .000 & .062 \\
\hline & $\overline{\mathrm{N}}$ & 100 & 100 & 100 & 100 \\
\hline \multirow[t]{3}{*}{$\begin{array}{l}\text { Arranging the informal } \\
\text { sector }\end{array}$} & $\begin{array}{l}\text { Correlation } \\
\text { Coefficient }\end{array}$ &, $262^{* *}$ & $350^{* * *}$ & 1.000 & .192 \\
\hline & Sig. (2-tailed) & .008 & .000 & & .056 \\
\hline & $\mathrm{N}$ & 100 & 100 & 100 & 100 \\
\hline \multirow[t]{3}{*}{ Tax evasion rang } & $\begin{array}{l}\text { Correlation } \\
\text { Coefficient }\end{array}$ & .195 & .187 & .192 & 1.000 \\
\hline & Sig. (2-tailed) & .052 & .062 & .056 & . \\
\hline & $\mathrm{N}$ & 100 & 100 & 100 & 100 \\
\hline
\end{tabular}

**. Correlation is significant at the 0.01 level (2-tailed).

*. Correlation is significant at the 0.05 level (2-tailed). 


\section{References}

Allingham, M. G., \& Sandmo, A. (1972). Income Tax Evasion: A Theoretical Analysis. Journal of Public Economic, 1, 323-338. https://doi.org/10.1016/0047-2727(72)90010-2

Alm, J. (2012). Measuring, Explaining, and Controlling Tax Evasion: Lessons from Theory, Experiments, and Field Studies. Tulane Economics Working Paper Series 1213. https://doi.org/10.1007/s10797-011-9171-2

Devos, K. (2014). Factors Influencing Individaul Taxpayer Compliance Behavior. Springer Science+Business Med.

Fisher, R. (1922). On the interpretation of $\chi 2$ from contingency tables, and the calculation of P. J. R. Stat. Soc., 85, 87-94. https://doi.org/10.2307/2340521

Fisher, R. (1924). The conditions under which $\chi 2$ measures the discrepancy between observation and hypothesis. $J . R$. Stat. Soc., 87, 442-450.

Kerzner, S. D., \& Chodikoff, W. D. (2016). International Tax Evasion in the Global Information Age. Palgrave Macmillan imprint is published by Springer Nature. https://doi.org/10.1007/978-3-319-40421-9

Kirchler, E. (2009). The Economic Psychology of Tax Behaviour. Cambridge University Press.

McGee, W. R., \& Tyler, M. (2006). Tax Evasion and Ethics: A Demographic Study of 33 Countries. Andreas School of Business Working Paper, Barry University, Miami:1-20.

McGee, W. R., Basić, M., \& Tyler, M. (2006). The Ethics of Tax Evasion: A Survey of Bosnian Opinion. Presented at the Fifteenth Annual World Business Congress (IMDA) Sarajevo. https://doi.org/10.2139/ssrn.899609

Pickhardt, M., \& Prinz, A. (2013). Behavioral dynamics of tax evasion-A survey. Journal of Economic Psychology (in Press), 1-19.

Pyle, D. (1989). Tax evasion and the black economy. St. Martin's Press, New York. https://doi.org/10.1007/978-1-349-08488-3

Russo, F. F. (2010). Tax Evasion and Community Effects in Italy. CSEF Centre for Studies in Economics and Finance Working paper no. 254.

Schneider, F., \& Buehn, A. (2016). Estimating the Size of the Shadow Economy: Methods, Problem and Open Questions. IZA Discussion Paper No. 9820.

TADAT Secretariat. (2015). Tax Administration Diagnostic Assessment Tool. Filed Guide prepared by the IMF.

Turner, C. S. (2010). Essays in Crime and tax Evasion. Economics Dissertation Paper 64.

\section{Copyrights}

Copyright for this article is retained by the author(s), with first publication rights granted to the journal.

This is an open-access article distributed under the terms and conditions of the Creative Commons Attribution license which permits unrestricted use, distribution, and reproduction in any medium, provided the original work is properly cited. 